\title{
Long-term effects of straw and straw-derived biochar on soil aggregation and fungal community in a rice-wheat rotation system
}

\author{
Naling Bai ${ }^{1,2}$, Hanlin Zhang ${ }^{1,2}$ ，Shuangxi Li ${ }^{1,2}$, Xianqing Zheng ${ }^{1,2}$ ， Juanqin Zhang ${ }^{1,2}$, Haiyun Zhang ${ }^{1,2}$ \\ Sheng Zhou ${ }^{1,2}$, Huifeng Sun ${ }^{1,2}$, Weiguang Lv ${ }^{\text {corresp. 1, 2, } 3}$ \\ ${ }^{1}$ Shanghai Academy of Agricultural Science, Eco-environmental Protection Research Institute, Shanghai, China \\ 2 Agricultural Environment and Farmland Conservation Experiment Station of Ministry Agriculture, Shanghai, China \\ 3 Shanghai Key Laboratory of Protected Horticultural Technology, Shanghai, China \\ Corresponding Author: Weiguang LV \\ Email address: Ivweiguang@saas.sh.cn
}

Background Soil aggregation is fundamental for soil functioning and agricultural productivity. Aggregate formation depends on microbial activity influencing the production of exudates and hyphae, which in turn act as binding materials. Fungi are also important for improving soil quality and promoting plant growth in a symbiotic manner. There is a scarcity of findings comparing the long-term impacts of different yearly double-crop straw return modes (e.g., straw return to the field and straw-derived biochar return to the field) on soil aggregation and fungal community structure in rice-wheat rotation systems.

Methods The effects of 6-year continuous straw and straw-derived biochar amendment on soil physicochemical properties and the fungal community were evaluated in an intensively managed crop rotation system (rice-wheat). Soil samples of different aggregates (macroaggregates, microaggregates, and silt clay) from four different fertilization regimes (control, CK; traditional inorganic fertilization, CF; straw returned to field, CS; straw-derived biochar addition, CB) were obtained, and Illumina MiSeq sequencing analysis of the fungal internal transcribed spacer (ITS) gene was performed. Results Compared to CF, CS and CB enhanced soil organic carbon (SOC), total nitrogen (TN), and aggregation in 0-20 and $20-40 \mathrm{~cm}$ soil, with CB exhibiting a stronger effect. Additionally, agrowaste addition increased the mean weight diameter (MWD) and the geometric diameter (GMD) and decreased the fractal dimension (D) $(p<0.05)$. Principal coordinates analysis indicated that fertilization management affected fungal community structure and aggregation distribution. In addition, CS increased fungal community richness and diversity, compared to CK, CB decreased these aspects. Ascomycota, unclassified_k_Fungi, and Basidiomycota were the dominant phyla in all soil samples. At the genus level, CB clearly increased fungi decomposing biosolids (Articulospora in macroaggregates in $0-20 \mathrm{~cm}$ soil and Neurospora in macroaggregates in $20-40 \mathrm{~cm}$ soil); 
decreased pathogenic fungi (Monographella in macroaggregates and Gibberella in microaggregates in 0-20 cm soil) and $\mathrm{CO}_{2}$-emission-related fungi (Pyrenochaetopsis in microaggregates and silt clay in $0-40 \mathrm{~cm}$ soil) $(p<0.05)$. Straw and biochar with inorganic fertilizer counteracted some of the adverse effects of the inorganic fertilizer with biochar showing better effects than straw. 
1 Long-term effects of straw and straw-derived biochar

2 on soil aggregation and fungal community in a rice-

3 wheat rotation system

4 Naling Bai ${ }^{1,2 \#}$, Hanlin Zhang ${ }^{1,2 \#}$, Shuangxi $\mathrm{Li}^{1,2}$, Xianqing Zheng ${ }^{1,2}$, Juanqin Zhang ${ }^{1,2}$, Haiyun

5 Zhang ${ }^{1,2}$, Sheng Zhou ${ }^{1,2}$, Huifeng Sun ${ }^{1,2}$, Weiguang $\mathrm{Lv}^{1,2,3^{*}}$

6

$7 \quad{ }^{1}$ Eco-environmental Protection Research Institute, Shanghai Academy of Agricultural Science,

8 Shanghai 201403, China

$9 \quad{ }^{2}$ Agricultural Environment and Farmland Conservation Experiment Station of Ministry of

10 Agriculture, Shanghai 201403, China

$11{ }^{3}$ Shanghai Key Laboratory of Protected Horticultural Technology, Shanghai, 201403, China

$12{ }^{\#}$ Contributed equally to this work.

Corresponding Author:

15 Weiguang Lv

Eco-environmental Protection Research Institute, Shanghai Academy of Agricultural Science, Shanghai, 201403, P. R. China.

Email address: lvweiguang@saas.sh.cn

\section{Abstract}

\section{Background}

Soil aggregation is fundamental for soil functioning and agricultural productivity. Aggregate formation depends on microbial activity influencing the production of exudates and hyphae, which in turn act as binding materials. Fungi are also important for improving soil quality and promoting plant growth in a symbiotic manner. There is a scarcity of findings comparing the long-term impacts of different yearly double-crop straw return modes (e.g., straw return to the 
27 field and straw-derived biochar return to the field) on soil aggregation and fungal community

28 structure in rice-wheat rotation systems.

\section{Methods}

30 The effects of 6-year continuous straw and straw-derived biochar amendment on soil physicochemical properties and the fungal community were evaluated in an intensively managed crop rotation system (rice-wheat). Soil samples of different aggregates (macroaggregates, microaggregates, and silt clay) from four different fertilization regimes (control, $\mathrm{CK}$; traditional inorganic fertilization, CF; straw returned to field, CS; straw-derived biochar addition, CB) were obtained, and Illumina MiSeq sequencing analysis of the fungal internal transcribed spacer (ITS) gene was performed.

\section{Results}

Compared to CF, CS and CB enhanced soil organic carbon (SOC), total nitrogen (TN), and aggregation in 0-20 and 20-40 cm soil, with CB exhibiting a stronger effect. Additionally, agrowaste addition increased the mean weight diameter (MWD) and the geometric diameter (GMD) and decreased the fractal dimension (D) $(p<0.05)$. Principal coordinates analysis indicated that fertilization management affected fungal community structure and aggregation distribution. In addition, CS increased fungal community richness and diversity, compared to CK, CB decreased these aspects. Ascomycota, unclassified_k_Fungi, and Basidiomycota were the dominant phyla in all soil samples. At the genus level, CB clearly increased fungi decomposing biosolids (Articulospora in macroaggregates in 0-20 cm soil and Neurospora in macroaggregates in 20-40 cm soil); decreased pathogenic fungi (Monographella in macroaggregates and Gibberella in microaggregates in $0-20 \mathrm{~cm}$ soil) and $\mathrm{CO}_{2}$-emission-related fungi

49 (Pyrenochaetopsis in microaggregates and silt clay in $0-40 \mathrm{~cm}$ soil) $(p<0.05)$. Straw and

50 biochar with inorganic fertilizer counteracted some of the adverse effects of the inorganic

51 fertilizer with biochar showing better effects than straw.

\section{Introduction}

53 Soil aggregation, which is largely responsible for soil structure, is fundamental for soil 
54 functioning and agricultural productivity (Zhao et al. 2018). Aggregate formation depends on

55

56

57

58

59

60

microbial activity influencing the production of exudates and hyphae, which in turn act as binding materials. Generally, soil aggregate dynamics are influenced by a number of factors, including (i) the soil biota (both microorganisms and macrofauna), (ii) the availability of inorganic binding agents, (iii) root growth, (iv) soil mineralogy and texture, and (v) environmental conditions (Six et al. 2004).

Soil microbial community abundance and structure have been widely used to indicate soil quality changes since they are sensitive to environmental changes. Fungi are also important soil microorganisms as, just like bacteria, they are capable of decomposing complex carbon compounds, improving soil quality, and promoting plant growth in a symbiotic manner. A fungus-dominant microbial community is important for carbon (C) stabilization and can produce more protected and stable C storage (Six et al. 2006). The microbial community is greatly affected by anthropogenic activities, such as agricultural intensification and fertilization (Ding et al. 2017). In long-term fertilizer experiments, the community structure, population and function of microorganisms are all affected (Cinnadurai et al. 2013). For example, nitrogen (N) fertilizer and $\mathrm{N}$ plus Phosphate $(\mathrm{P})$ fertilizers increase the size of fungi, reduce fungal biodiversity and change the community composition (Zhou et al. 2016). A combination of organic amendment and inorganic fertilizer not only recycles resources and improves soil fertility but also impacts soil fungal diversity (Ding et al. 2017).

Straw is rich in organic carbon, nitrogen, phosphorus, potassium, silicon, and other mineral nutrients. Crop straw can be used for cellulosic feedstock, renewable energy, paper-making, and animal feed. However, in most cases, straw has been usually either burned or discarded, which is a great waste of raw materials. Effective utilization of agro-waste, e.g., straw, is a priority issue for the sustainable development of resources, environment, and agriculture (Cui et al. 2017). Relative to a control, straw return significantly increased the proportion of macroaggregates in the $0-20 \mathrm{~cm}$ soil layer and the soil organic carbon (SOC) content in each soil aggregate size class (Zhao et al. 2018). Straw and straw-derived biochar have attracted increasing attention in China; 
81 furthermore, the pyrolysis conversion of crop straw into biochar avoids the problem of the slow

82 decomposition rate of straw in soil. Furthermore, biochar increases soil carbon sequestration more than straw (Cui et al. 2017).

The nutrients and effects of biochar can vary considerably depending on the feedstock, pyrolysis conditions, and application environment. Therefore, the interactions between biochar and microorganisms might be quite complicated. Generally, biochar holds promise as an amendment for soil quality improvement, sequestration of atmosphere $\mathrm{CO}_{2}$, and increasing crop productivity (Feng et al. 2012). Some studies also revealed that biochar addition can negatively impact soil properties. For example, Warnock et al. (2010) reported that biochar (lodgepole pine, peanut shell, and mango wood) application decreased arbuscular mycorrhizal fungal abundance in roots or soils. A lower microbial metabolic quotient and enzyme activity were observed in a rice paddy four years after a single incorporation of 20 and $40 \mathrm{tha}^{-1}$ biochar (Zheng et al. 2016). Additionally, Jindo et al. (2012) found that biochar addition increased the microbial community and influenced the performance of the composting process. Fungal community composition was more affected by biochar than bacterial community composition (Zheng et al. 2016). Abujabhah et al. (2016) noted that in orchard soil, the effect of biochar and compost addition on fungal community structure alteration was the most highly significant, whereas a smaller difference was observed for the overall bacterial community structure.

Numerous studies have shown the short-term impacts of either straw or biochar on the soil microbial community (Ameloot et al. 2013; Wang et al. 2017a). In finer-textured Yolo soil, 1\% walnut shell biochar decreased the fungi to bacteria ratio with an increase in total phosphlipid fatty acids (PLFA) (Wang et al. 2017a). Chen et al. (2017) found that under short-term straw return, straw application significantly increased total PLFA, bacterial biomass and actinomycete biomass in Jiangyan, but had no significant effects on PLFAs in both Qujialing and Guangde, relative to no straw return treatment. However, to our knowledge, there is a scarcity of findings comparing the long-term impacts of different yearly double-crop straw return modes (e.g., straw return to the field and straw-derived biochar return to the field) on soil aggregate and fungal 
108

109

110

111

112

113

114

115

116

117

118

119

120

121

122

123

124

125

126

127

128

129

130

131

132

133

134

community structure in rice-wheat rotation systems. Thus, our objectives were to apply Illumina MiSeq high-throughput sequencing to analyze (i) the influence of straw and straw-derived biochar on aggregate distribution and stabilization and (ii) the effects of fertilization management and aggregation on fungal community structure.

\section{Materials \& Methods}

\section{Experimental design}

An in situ 6-year field study was operated with a typical rice-wheat rotation system in a sandy loam soil at Zhuanghang Field Station, Shanghai Academy of Agricultural Sciences, China $\left(30^{\circ} 53^{\prime} \mathrm{N}, 121^{\circ} 23^{\prime} \mathrm{E}\right)$. Treatments were denoted in triplicate as follows: (i) CK (no fertilizer application), (ii) CF (conventional inorganic fertilizer application), (iii) CS (the same total pure nitrogen application as in CF plus $3 \mathrm{tha}^{-1}$ straw returning to the field), and (iv) $\mathrm{CB}$ (the same total pure nitrogen application as in CF plus $1 \mathrm{t} \mathrm{ha}^{-1}$ straw-derived biochar returning to the field). The experimental plots were arranged in a completely randomized block with each area being 60 $\mathrm{m}^{2}$.

The application amounts of pure N, P, and potassium (K) for rice were $225,112.5$, and $255 \mathrm{~kg}$ $\mathrm{ha}^{-1}$, respectively. For wheat season, the corresponding amounts were 180, 90, and $204 \mathrm{~kg} \mathrm{ha}^{-1}$, respectively. The $\mathrm{N}$ deficiencies in $\mathrm{CS}$ and $\mathrm{CB}$ were complemented by inorganic $\mathrm{N}$ fertilizer. The $\mathrm{N}, \mathrm{P}$, and $\mathrm{K}$ fertilizers used in the experiment were urea, calcium superphosphate, and potassium sulfate, respectively. Straw or biochar was added to the soil surface and thoroughly mixed with a depth of approximately $15 \mathrm{~cm}$. Rice/wheat straw and the derived biochar were continuously sent back to the land as amendments in wheat/rice season. Pyrolysis was anaerobically performed at $500-600{ }^{\circ} \mathrm{C}$ in a vertical charcoal furnace (ECO-5000, Wuneng Environment Co., Ltd., Zhejiang, China) for biochar preparation. The basic characteristics of the straw and biochar are listed in Table S1.

\section{Soil sample collection and analysis}

In June 2016, after wheat harvest, samples were aseptically taken from the 0-20 and 20-40 cm soil layers using a five-point sampling method. The samples were stored in polyethylene bags at 
135

136

137

138

139

140

141

142

143

144

145

146

147

148

149

150

151

152

153

154

155

156

157

158

159

$160 \quad \mathrm{GMD}=\exp \left(\frac{\sum_{\mathrm{i}=1}^{\mathrm{n}} \mathrm{W}_{\mathrm{i}} \ln \mathrm{X}_{\mathrm{i}}}{\sum_{\mathrm{i}=1}^{\mathrm{n}} \mathrm{W}_{\mathrm{i}}}\right)($ Eq. 2) determination. respectively.

\section{Aggregate size distribution} oven-dried.

$\mathrm{MWD}=\sum_{\mathrm{i}=1}^{\mathrm{n}} \mathrm{X}_{\mathrm{i}} \mathrm{W}_{\mathrm{i}}$ (Eq. 1)

low temperature and immediately returned to the laboratory. Then, the samples were sieved to remove roots, rocks, and litter. Approximately $100 \mathrm{~g}$ of sieved soil was subjected to different aggregate classifications and subsequently frozen at $-80{ }^{\circ} \mathrm{C}$ for fungal community analysis. The residual portions of soil samples were further air-dried for physicochemical property

Soil $\mathrm{pH}$ was measured by potentiometry with a soil-water ratio of 1:2.5 (Mettler Toledo, Switzerland). Gravimetric moisture content was determined by weighing the soil, followed by drying the soil samples at $105^{\circ} \mathrm{C}$ for $24 \mathrm{~h}$ and weighing the soil again. $\mathrm{NH}_{4}{ }^{+}-\mathrm{N}$ and $\mathrm{NO}_{3}{ }^{-}-\mathrm{N}$ were assayed with Nessler's reagent and the phenol disulfonic acid colorimetric methods, respectively. SOC and total nitrogen (TN) contents were determined with an elemental analyzer (Elementar, Germany) and an automatic nitrogen determination instrument (KDN-08C, Shanghai, China),

Soil water-stable aggregates were separated by an agglomerate analyzer according to the wet sieving method with some modifications (Elliott 1986). Briefly, a series of sieves was used to obtain three aggregate classes: macroaggregates $(>0.25 \mathrm{~mm})$, microaggregates $(0.053-0.25 \mathrm{~mm})$, and silt clay $(<0.053 \mathrm{~mm})$. First, the soil samples were slowly wetted for $5 \mathrm{~min}$ using sterile water. The analyzer was then shaken up and down at 20 times min $^{-1}$ for 5 min with the column submerged in water throughout the whole process. The fractions remaining on each sieve were collected at the end of sieving. Aggregates in the beakers were stored at $-80^{\circ} \mathrm{C}$ for microbial analysis, and the remaining portions were weighed to analyze the relative indices after being

The mean weight diameter (MWD) represents aggregate stability and was calculated using Eq. 1:

The geometric mean diameter (GMD) was calculated using Eq. 2: 
161

162

163

164

165

166

167

168

169

170

171

172

173

174

175

176

177

178

179

180

181

182

183

184

185

186

187

where $\mathrm{i}$ corresponds to each collected fraction, and $\mathrm{X}_{\mathrm{i}}$ and $\mathrm{W}_{\mathrm{i}}$ refer to the mean diameter and the dry weight of i-size aggregates, respectively.

The fractal dimension (D) was obtained by regression analysis using Eq. 3:

$(3-D) \lg \left(\frac{d_{i}}{d_{\max }}\right)=\lg \left[\frac{W_{\left(\delta \leq d_{i}\right)}}{W_{0}}\right]$ (Eq. 3)

where $\mathrm{d}_{\mathrm{i}}, \mathrm{d}_{\max }, \mathrm{W}_{(\delta \leq \mathrm{di})}$, and $\mathrm{W}_{0}$ refer to the average diameter of an i-size aggregate, the maximum diameter of all aggregates tested, the weight of aggregates with particle size $<\mathrm{d}_{\mathrm{i}}$, and the total weight of aggregates, respectively. Finally, D was obtained by regression analysis.

\section{Fungal DNA extraction and high-throughput pyrosequencing}

Aggregate DNA was extracted using the MoBio PowerSoil Soil ${ }^{\circledR}$ DNA Isolation Kit (12888) according to the manufacturer's instructions. An aliquot of the DNA extracted from each sample was used as a template for amplification after its quality was confirmed by spectrophotometer (RS232G, Eppendorf, Germany). The internal transcribed spacer (ITS) regions were amplified with the primers ITS1F (5'-CTTGGTCATTTAGAGGAAGTAA-3') and ITS1R (5'GCTGCGTTCTTCATCGATGC -3'). PCR amplification was conducted as follows: $30 \mathrm{~s}$ of initial denaturation at $98^{\circ} \mathrm{C}$, followed by 35 cycles of denaturation at $98^{\circ} \mathrm{C}$ for $15 \mathrm{~s}$, annealing at $50{ }^{\circ} \mathrm{C}$ for $30 \mathrm{~s}$, extension at $72{ }^{\circ} \mathrm{C}$ for $30 \mathrm{~s}$, and a final extension at $72{ }^{\circ} \mathrm{C}$ for $5 \mathrm{~min}$. Sequencing was performed on a MiSeq PE300 platform at Majorbio Biotechnology Co. Ltd. (Shanghai, China).

The original data fragments were quality-controlled using Trimmomatic software, merged with FLASH and analyzed using Quantitative Insights into Microbial Ecology (QIIME) software. Operational taxonomic units (OTUs) with 97\% similarity were clustered using USEARCH 7.0 and analyzed against the UNITE database (Release $6.0 \mathrm{http} / /$ unite.ut.ee/index.php) with a confidence threshold of $70 \%$. All sequences have been deposited in the NCBI Short Reads Archive database (Accession Number: SRP161464).

\section{Statistical analysis}

The data were analyzed on the free online Majorbio I-Sanger Cloud Platform (www.isanger.com). Principal coordinates analysis (PCoA) was carried out to investigate the fungal 
188

189

190

191

192

193

194

195

196

197

198

199

200

201

202

203

204

205

206

207

208

209

210

211

212

213

214

community differences between four different treatments based on OTU results using R software. Significant differences between the trial treatments were determined by ANOVA analysis using SPSS 16.0 software (SPSS Corp., Chicago, IL, USA). Significant differences between means were determined with the least significant difference (LSD) test at the $p=0.05$ level. Figures were prepared using ORIGIN 8.0 (OriginLab Corporation, Northampton, MA, USA).

\section{Results}

\section{Soil agrochemical properties}

Soil nutrient contents were measured to investigate the influence of different fertilization treatments on soil physiochemical properties (Table 1). For the $0-20 \mathrm{~cm}$ soil depth, $\mathrm{CB}$ had the highest SOC content compared to CF and CK $(p<0.05)$; the difference with CS was not significant. Compared to CF, CS and CB both significantly increased the SOC and TN contents in 20-40 $\mathrm{cm}$ soil $(p<0.05)$. CS had a lower soil $\mathrm{pH}$ than $\mathrm{CK}$ in the $0-20 \mathrm{~cm}$ layer $(p<0.05)$, which may be due to more anions being released during straw decomposition. In 20-40 cm soil, CB had a higher electrical conductivity (EC) value than CS $(p<0.05)$.

\section{Water-stable aggregate distribution and stability analysis}

Macroaggregates were the dominant aggregate size class in both 0-20 and 20-40 cm layers (Fig.

1). $\mathrm{CS}$ and $\mathrm{CB}$, compared with $\mathrm{CF}$, dramatically increased the macroaggregate content by $17.77 \%$ $18.87 \%$ and $33.55 \%-50.87 \%$ in the $0-20$ and $20-40 \mathrm{~cm}$ soil layers, respectively, with CB performing more remarkably $(p<0.05)$. In terms of microaggregates, compared to $\mathrm{CF}, \mathrm{CS}$ decreased its mass proportion in the $0-20 \mathrm{~cm}$ soil layer by $11.61 \%$; CB reduced its content in 20 $40 \mathrm{~cm}$ soil layer by $25.84 \%(p<0.05)$. For silt clay content, compared to CF, CS and CB showed dramatic decreases of $39.46 \%-66.12 \%$ and $40.40 \%-50.99 \%$ in the surface soil and deep soil, respectively $(p<0.05)$.

Aggregate stability is an influential factor governing soil erodibility (Ahmadi et al. 2011). MWD and GMD have commonly been used as indicators to reflect agglomeration aggregation and the stability of soil aggregates. Compared to CF, CS and CB increased MWD and GMD values at soil depths of 0-20 cm (16.92\%-29.23\%, 29.41\%-47.06\%) and 20-40 cm (23.915\%-30.43\%, 
215

216

217

218

219

220

221

222

223

224

225

226

227

228

229

230

231

232

233

234

235

236

237

238

239

240

241

39.13\%-43.48\%), respectively; CB exhibited a more prominent effect than CS $(p<0.05)$ (Table

2), indicating that organic amendment facilitates aggregate stability. D was used to indicate the size, distribution, and homogeneity of the soil particles; the higher the value, the poorer the soil permeability (Ahmadi et al. 2011). CS and CB remarkably reduced the D value by $1.22 \%-1.49 \%$ and $0.44 \%-0.60 \%$ at the $0-20$ and $20-40 \mathrm{~cm}$ soil depths, respectively, which verified that straw and straw biochar promoted the uniform distribution of soil aggregates.

\section{Sequence data and alpha diversity}

A total of 4,245,052 sequences with an average length of $258 \mathrm{bp}$ were obtained from all 72 samples. Fertilization affected soil fungal abundance in different aggregates (Fig. S1). In the 0$20 \mathrm{~cm}$ soil layer, the number of fungal OTUs was inversely related to the aggregate size; CB harbored the smallest number of OTUs of the treatments $(636,831$, and 872 in macroaggregate, microaggregate, and silt clay, respectively), which was inconsistent with previous reports that the proportion of fungal groups in macroaggregates is high, indicating a major role in their formation. In the $20-40 \mathrm{~cm}$ soil, no such remarkable tendency was observed.

Alpha analysis of the fungal community under different treatments at different soil depths was estimated using Student's t-test (Fig. 2). The Chao1 estimator, abundance-based and coverage estimator (ACE), and observed richness (Sobs) were employed as community richness indices (Liu et al. 2015). Significant variances were observed among the four treatments for in macroaggregates in surface soil. The Chao 1 and ACE values of CS were higher than those of $\mathrm{CK}(p<0.05, p<0.01$, respectively); higher Sobs values were observed in CS than in CK, CF, and CB $(p<0.05)$. As for both microaggregates and silt clay, no significant difference was observed between the four treatments in the $0-20 \mathrm{~cm}$ soil layer, suggesting that fungi played a more important role in large aggregate formation ( $\mathrm{Li}$ et al. 2018). The Shannon and Simpsoneven indices, calculated by richness and species abundance, were used as diversity and evenness indices, respectively, within each individual sample. Compared to CS, CB decreased the Shannon index in macroaggregates in $0-20 \mathrm{~cm}$ soil $(p<0.05)$; no difference was observed with the other treatments. In deep-layer soil, microaggregates in CF had a dramatically lower 
242 Simpsoneven value than CK $(p<0.05)$, which suggested that long-term chemical fertilization

243 probably impairs the evenness of the fungal community.

\section{Comparison of fungal community structure}

245 PCoA was used to investigate the variations in fungal community structure caused by long-term

246 fertilization and aggregate distribution (Fig. 3). For the surface soil, samples of CB were

247 separated with the other three treatments by PC1 (35.48\%); CS samples were gathered at the

248 bottom left corner of the graph, apart from CK and CF, by PC2 (19.86\%). CK and CF showed

249 similar fungal community structures, as they were located in the upper part of PC2. With respect

250 to the 20-40 cm soil layer, CF and CB were separated from CS and CK by PC2 (19.66\%); PC1

251 (30.39\%) approximately differentiated CB from CK and CF. Non-metric multidimensional

252 scaling (NMDS) analysis based on Pearson distances, in accordance with the PCoA results,

253 presented stress values of 0.098 and 0.091 for top soil $(0-20 \mathrm{~cm})$ and deep soil $(20-40 \mathrm{~cm})$,

254 respectively (Fig. S2). The fungal community structures in CS and CB were significantly

255 different from those in CF and CK at the 97\% OTU level, and that of CS was significantly

256 different from that of CB.

\section{Fungal community composition}

258 Fertilization, agglomerate levels and sampling depth all can largely alter the community

259

260

261

262

263

264

265

266

267

268

composition of soil fungi. In the top layer of soil, the phyla Ascomycota, unclassified_k_Fungi, and Basidiomycota constituted over $97 \%$ of sequences (Fig. S3). Ascomycota was the most prevalent phylum in the soil; its members are known for their ability to degrade lignin, but it also includes many sugar fungi that utilize simple substrates (Chen et al. 2013). The other less dominant phyla were Zygomycota, Glomeromycota, and Chytridiomycota. At the class level, fertilization management played an important role in the relative abundance of fungi (Fig. 4 and 5). Fig. 5A-E and F-J showed the statistically differences of the representative classes in the aggregates in $0-20 \mathrm{~cm}$ and $20-40 \mathrm{~cm}$, respectively. In the $0-20 \mathrm{~cm}$ soil layer, $\mathrm{CB}$, compared to $\mathrm{CF}$, decreased Dothideomycetes in all three aggregates and Glomeromycetes in silt clay $(p<0.05)$. Leotiomycetes contents in macroaggregates and silt clay in the $0-20 \mathrm{~cm}$ soil were significantly 
269 higher in CB than CF $(p<0.05)$. A similar phenomenon was observed in the deep-layer $(20-40$

$270 \mathrm{~cm}$ ) soil to variable extents. In macroaggregates, fertilization decreased and increased the relative

271 abundances of Dothideomycetes (in both macroaggregates and silt clay) and Sordariomycetes (in

272 macroaggregates), respectively, with CB significantly differing from $\mathrm{CK}(p<0.05)$. In

273 microaggregates, fertilizer application resulted in trends of decreased Chytridiomycetes and

274 unclassified_k_Fungi. CF possessed higher Glomeromycetes content in silt clay than CK and CB

$275(p<0.05)$.

276 The statistical analysis results for the relevant abundances of the dominant fungal genera are

277 shown in Table $3(0-20 \mathrm{~cm})$ and Table $4(20-40 \mathrm{~cm})$. At 0-20 cm, CB, compared to CF, reduced

278 the contents of Monographella (macroaggregate), Pyrenochaetopsis (microaggregate and silt

279 clay), and Gibberella (microaggregate) and increased Articulospora content (macroaggregate) ( $p$

$280<0.05)$. CS also lowered the relative abundances of Pyrenochaetopsis (silt clay) and Gibberella

281 (microaggregate) relative to $\mathrm{CF}(p<0.05)$. As for the $20-40 \mathrm{~cm}$ soil, $\mathrm{CB}$, compared with $\mathrm{CF}$,

282 decreased Pyrenochaetopsis (microaggregate and silt clay) and increased Neurospora

283 (macroaggregate) $(p<0.05)$. CS had lower Pyrenochaetopsis (microaggregate) and higher

284 Neosetophoma contents than CF $(p<0.05)$. Additionally, a small number of "unclassified"

285 sequences were identified in this study, which means that these soils contained several

286 unidentified fungi.

\section{Discussion}

288 Straw/biochar application tended to increase SOC and TN contents in both the 0-20 and 20-40

$289 \mathrm{~cm}$ soil layers (Table 1). It seemed that CB treatment performed better than CS in our experiment.

290 Biochar addition stimulates soil $\mathrm{C}$ sequestration by improving the aggregation, stabilization of

291 soil organic matter with aggregates, and facilitating the physical protection of C (Wang et al.

292 2017a), which was more prominent than the results achieved wit straw (Huang et al. 2018).

293 Biochar addition can also reduce the amount of $\mathrm{N}$ leaching, due to its porous nature and large

294 surface area, and hence increase soil nitrogen (Xu et al. 2016). Three fertilization treatments

295 decreased the soil $\mathrm{pH}$ relative to $\mathrm{CK}$ to some extent (Table 1). However, the modulation of soil 
296

297

298

299

300

301

302

303

304

305

306

307

308

309

310

311

312

313

314

315

316

317

318

319

320

321

322

$\mathrm{pH}$ may be less pronounced in soils with a near neutral $\mathrm{pH}$ (Chen et al. 2013). The driving force

behind a $\mathrm{pH}$ decrease is the oxidation of $\mathrm{C}$ to form acidic carboxyl groups, whereas an increase is likely related to the dissolution of alkaline minerals (Lehmann et al. 2011). Unlike laboratory incubations, field experiments are characterized by changing temperatures, frequency of tillage, and cycling of wetting and drying, which may decrease the impacts of biochar on both soil chemical and biological properties.

The results verified that extra organic biomass addition increased proportion of macroaggregates and reduced the portion of microaggregates and silt clay particles (Fig. 1). Biochar, produced at a lower temperature in our study, still contained a relatively large amount of nonpyrolyzed organic residue, which could potentially increase both microbial activity and soil aggregation by providing feedstock for the production of extracellular polymeric substances acting as cementing agents for soil aggregates (Wang et al. 2017a). Zhao et al. (2018) reported similar results regarding the mass proportions of different aggregates with straw return to fields. However, their differences in the 20-40 cm layer were not significant, since the effects of fertilization on soil aggregation generally occur in the surface soil. Here, a significant difference was observed in 0$40 \mathrm{~cm}$ soil, which may be explained by years of returning straw to the field or soil conditions. Wang et al. (2017a) noticed that the addition of softwood biochar and walnut shell biochar both dramatically improved aggregate stability in Yolo soil (silty loam) but had no significant impact in Vina soil (fine sandy loam), which verified that the effects of biochar on soil quality are complicated.

Alpha diversity analysis showed that straw tended to increase fungal community richness and diversity, but straw biochar had the opposite tendency (Fig. 2). CF decreased fungal richness in this study, which was in contrast with the results reported by Wang et al. (2017b). The C:N ratio in soil is among the strongest correlates of fungal community composition and related to community differentiation between fertilizer treatments (Schlatter et al. 2017). Organic nitrogen supplied via biochar may slow the fungal community response to increased surface residue and reduce the rate of residue breakdown (Schlatter et al. 2017). Small molecule compositions in 
323

324

325

326

327

328

329

330

331

332

333

334

335

336

337

338

339

340

341

342

343

344

345

346

347

348

349

organic matter can also strictly control the development and abundance of soil microbial communities, although they increase the soil total C and N (Cozzolino et al. 2016). Furthermore, the reduction in soil tensile strength by biochar addition may also make it physically easier for invertebrates to move through the soil, altering predator/prey dynamics and thus reducing fungal contents (Atkinson et al. 2010; Chen et al. 2013), since bulk density has a positive correlation with bacterial biomass and a negative correlation with fungal biomass (Jindo et al. 2012). Thus, the effects of organic amendment are likely feedstock-, soil-, and plant-specific, although this conclusion requires further verification (Lehmann et al. 2011).

PCoA analysis indicated that fertilization and soil aggregation both affected fungi community structure by (Fig. 3). Several studies have reported similar tendencies. Both bacterial and fungal community composition were clearly separated by the straw addition and zero addition treatments (Bei et al. 2018; Zheng et al. 2016). Ali et al. (2019) also reported that soil microbiological communities differed from those of the control treatment group after biochar addition, meaning that biochar amendment altered the microbial community structure. However, the difference between the three hierarchical aggregates was not remarkable in the present study. Biochar had a more significant role in fungal community structure than CS (visualized by PCoA). Fertilization methods have not been generally claimed to affect the microbial community (Ding et al. 2017; He et al. 2008; Maarastawi et al. 2018). Wang et al. noted that CF could increase fungal richness (Wang et al. 2017b); however, CF decreased fungal richness in the present study. Here, using the MiSeq sequencing platform, we analyzed the effects of different fertilization practices on fungal community composition and structure. At the class level, Sordariomycetes and Dothideomycetes together occupied the dominant position for 39.98\%-82.68\% (Fig. 4). Sordariomycetes was increased in macroaggregates in $20-40 \mathrm{~cm}$ soil (Fig. 5G), especially with the incorporation of biochar. Sordariomycetes was sensitive to fertilizers and responded to $\mathrm{N}$ addition with a nearly linear increase (Mueller et al. 2015). Fertilization seemed to decrease Dothideomycetes content in 0-40 cm soil, with the exception of CF in the $0-20 \mathrm{~cm}$ soil layer (Fig. 5A and F). Dothideomycetes, belonging to Ascomycota, is by far the largest and arguably most 
350

351

352

353

354

355

356

357

358

359

360

361

362

363

364

365

366

367

368

369

370

371

372

373

374

375

376

phylogenetically diverse class, containing a heterogeneous group of fungi that subsist in the majority of niches where fungi can be found. The best-known members of the group are plant pathogens that infect a broad range of hosts and cause severe crop losses (Gnavi et al. 2014; Ohm et al. 2012; Schoch et al. 2009). The relative abundance of Glomeromycetes, a fungal class regarded as widely symbiotic, decreased in response to drought (Ochoa-Hueso et al. 2018); thus, its content might have accordingly decreased during our sampling time (wheat season).

Leotiomycetes, increased by CS and CB in macroaggregates and silt clay (0-20 cm soil), usually comprises plant-associated fungi whose ecological roles include those of pathogens, endophytes, symbionts, and saprobes, and a large number of taxa whose ecology and nutritional modes are poorly understood but are assumed to be plant-based (Gnavi et al. 2014; Meerupati et al. 2013). Pyrenochaetopsis is one of the most abundant genera related to elevated atmosphere $\mathrm{CO}_{2}$ levels (Yu et al. 2018). Although it was one of the most abundant genera in a rice paddy amended with biochar, the mass application of biochar would lower its relative abundance (Zheng et al. 2016). In our present study, straw and biochar continuously returned to the field for 6 years, rather than in a large mass, had similar effects on aggregates in both $0-20 \mathrm{~cm}$ and $20-40 \mathrm{~cm}$ soils, with the exception of macroaggregates in 20-40 cm layer (Table 3). Therefore, $\mathrm{CO}_{2}$ emission variation in CS and CB needs further exploration. Gibberella and Monographella, which cause soil-borne diseases in crops (Tatagiba et al. 2016; Wang et al. 2018; Yan et al. 2018), were lower in CS and $\mathrm{CB}$ in the 0-20 cm layer, with their levels in $\mathrm{CB}$ exhibiting significant differences relative to those in CF $(p<0.05)$. These reduced pathogenic fungal contents might lessen the probability of morbidity. From this perspective, the application of organic amendments is a win-win strategy for the management of diseases caused by soil-borne pathogens (Bonanomi et al. 2010). Biochar amendment increased the content of Articulospora, which was dominant in decomposing plant litter (Seena et al. 2012), in macroaggregates $(0-20 \mathrm{~cm})$. Neurospora is known particularly for its abundant presence in ecosystems following fire (Schlatter et al. 2017); it was greatly enriched by straw biochar to decompose burnt biosolids in the present study (Table 4). Under our experimental conditions, these remarkable variations in fungal genera are likely related to and 
377 might be indicators of the effects of biochar amendment. CS also exhibited reactions

378 corresponding to these genera to different extents. In conclusion, straw and straw-derived

379 biochar applied with inorganic fertilizer affected fungal community structure and may have 380 overcome the adverse effects of inorganic fertilizer.

\section{Conclusions}

382 We conclude that the 6-year amendment of straw and straw-derived biochar improved soil 383 physicochemical properties and altered fungal community structure in a rice-wheat rotation system to different extents. With respect to aggregation and compared with $\mathrm{CF}, \mathrm{CS}$ and $\mathrm{CB}$ increased the content of macroaggregates $(>0.25 \mathrm{~mm})$ and decreased the contents of microaggregates $(0.053-0.25 \mathrm{~mm})$ and silt clay $(<0.053 \mathrm{~mm})$, with $\mathrm{CB}$ performing more prominently than CS $(p<0.05)$. In addition, CS increased fungal community richness and diversity, but $\mathrm{CB}$ decreased them. At the genus level, $\mathrm{CB}$ significantly increased fungi that decompose biosolids (Articulospora and Neurospora) and decreased pathogen fungi (Monographella and Gibberella) and $\mathrm{CO}_{2}$-emission-related fungi (Pyrenochaetopsis) in specific aggregates $(p<0.05)$. These remarkable variations in fungal genera are likely related to and might be indicators of the effects of biochar amendment. Furthermore, it seemed that fertilization management played an important role in fungal community structure and aggregation.

\section{Acknowledgements}

395 The authors are grateful for the anonymous reviewers for their constructive comments in improving both the language and scientific quality of the manuscript.

\section{Conflicts}

There were no conflicts for the publication.

\section{References}

Abujabhah IS, Bound SA, Doyle R, and Bowman JP. 2016. Effects of biochar and compost amendments on soil physico-chemical properties and the total community within a temperate agricultural soil. Applied Soil Ecology 98:243-253. https://doi.org/10.1016/j.apsoil.2015.10.021 
404 aggregates as an index of soil erodibility. Journal of Hydrology 400:305-311.

405 https://doi.org/10.1016/j.jhydrol.2011.01.045

406 Ali N, Khan S, Li Y, Zheng N, and Yao H. 2019. Influence of biochars on the accessibility of 407 organochlorine pesticides and microbial community in contaminated soils. Science of The Total 408 Environment 647:551-560. https://doi.org/10.1016/j.scitotenv.2018.07.425

409 Ameloot N, De Neve S, Jegajeevagan K, Yildiz G, Buchan D, Funkuin YN, Prins W, Bouckaert 410 L, and Sleutel S. 2013. Short-term $\mathrm{CO}_{2}$ and $\mathrm{N}_{2} \mathrm{O}$ emissions and microbial properties of biochar 411 amended sandy loam soils. Soil Biology and Biochemistry 57:401-410.

412 https://doi.org/10.1016/j.soilbio.2012.10.025

413 Atkinson CJ, Fitzgerald JD, and Hipps NA. 2010. Potential mechanisms for achieving 414 agricultural benefits from biochar application to temperate soils: a review. Plant and Soil 337:1415 18. 10.1007/s11104-010-0464-5

416 Bei S, Zhang Y, Li T, Christie P, Li X, and Zhang J. 2018. Response of the soil microbial 417 community to different fertilizer inputs in a wheat-maize rotation on a calcareous soil.

418 Agriculture, Ecosystems \& Environment 260:58-69. https://doi.org/10.1016/j.agee.2018.03.014

419 Bonanomi G, Antignani V, Capodilupo M, and Scala F. 2010. Identifying the characteristics of 420 organic soil amendments that suppress soilborne plant diseases. Soil Biology and Biochemistry 421 42:136-144. https://doi.org/10.1016/j.soilbio.2009.10.012

422 Chen J, Liu X, Zheng J, Zhang B, Lu H, Chi Z, Pan G, Li L, Zheng J, Zhang X, Wang J, and Yu 423 X. 2013. Biochar soil amendment increased bacterial but decreased fungal gene abundance with 424 shifts in community structure in a slightly acid rice paddy from Southwest China. Applied Soil 425 Ecology 71:33-44. https://doi.org/10.1016/j.apsoil.2013.05.003

426 Chen Z, Wang H, Liu X, Zhao X, Lu D, Zhou J, and Li C. 2017. Changes in soil microbial 427 community and organic carbon fractions under short-term straw return in a rice-wheat cropping 428 system. Soil and Tillage Research 165:121-127. https://doi.org/10.1016/j.still.2016.07.018 429 Cinnadurai C, Gopalaswamy G, and Balachandar D. 2013. Diversity of cultivable Azotobacter in 430 the semi-arid alfisol receiving long-term organic and inorganic nutrient amendments. Annals of 
431

432

433

434

435

436

437

438

439

440

441

442

443

444

445

446

447

448

449

450

451

452

453

454

455

456

457

Microbiology 63:1397-1404. 10.1007/s13213-013-0600-6

Cozzolino V, Meo VD, Monda H, Spaccini R, and Piccolo A. 2016. The molecular

characteristics of compost affect plant growth, arbuscular mycorrhizal fungi, and soil microbial community composition. Biology \& Fertility of Soils 52:15-29.

Cui Y-f, Meng J, Wang Q-x, Zhang W-m, Cheng X-y, and Chen W-f. 2017. Effects of straw and biochar addition on soil nitrogen, carbon, and super rice yield in cold waterlogged paddy soils of North China. Journal of Integrative Agriculture 16:1064-1074. https://doi.org/10.1016/S2095$3119(16) 61578-2$

Ding J, Jiang X, Guan D, Zhao B, Ma M, Zhou B, Cao F, Yang X, Li L, and Li J. 2017. Influence of inorganic fertilizer and organic manure application on fungal communities in a long-term field experiment of Chinese Mollisols. Applied Soil Ecology 111:114-122. https://doi.org/10.1016/j.apsoil.2016.12.003

Elliott ET. 1986. Aggregate Structure and Carbon, Nitrogen, and Phosphorus in Native and Cultivated Soils1. Soil Science Society of America Journal 50:627-633. $10.2136 /$ sssaj $1986.03615995005000030017 x$

Feng Y, Xu Y, Yu Y, Xie Z, and Lin X. 2012. Mechanisms of biochar decreasing methane emission from Chinese paddy soils. Soil Biology and Biochemistry 46:80-88.

https://doi.org/10.1016/j.soilbio.2011.11.016

Gnavi G, Ercole E, Panno L, Vizzini A, and Varese GC. 2014. Dothideomycetes and Leotiomycetes sterile mycelia isolated from the Italian seagrass Posidonia oceanica based on rDNA data. SpringerPlus 3:508. 10.1186/2193-1801-3-508

He J-Z, Zheng Y, Chen C-R, He Y-Q, and Zhang L-M. 2008. Microbial composition and diversity of an upland red soil under long-term fertilization treatments as revealed by culturedependent and culture-independent approaches. Journal of Soils and Sediments 8:349-358. $10.1007 / \mathrm{s} 11368-008-0025-1$

Huang R, Tian D, Liu J, Lv S, He X, and Gao M. 2018. Responses of soil carbon pool and soil aggregates associated organic carbon to straw and straw-derived biochar addition in a dryland 
458

459

460

461

462

463

464

465

466

467

468

469

470

471

472

473

474

475

476

477

478

479

480

481

482

483

484

cropping mesocosm system. Agriculture, Ecosystems and Environment 265:576-586.

https://doi.org/10.1016/j.agee.2018.07.013

Jindo K, Sánchez-Monedero MA, Hernández T, García C, Furukawa T, Matsumoto K, Sonoki T, and Bastida F. 2012. Biochar influences the microbial community structure during manure composting with agricultural wastes. Science of The Total Environment 416:476-481. https://doi.org/10.1016/j.scitotenv.2011.12.009

Lehmann J, Rillig MC, Thies J, Masiello CA, Hockaday WC, and Crowley D. 2011. Biochar effects on soil biota - A review. Soil Biology and Biochemistry 43:1812-1836.

https://doi.org/10.1016/j.soilbio.2011.04.022

Li F, Xue C, Qiu P, Liu Y, Shi J, Shen B, Yang X, and Shen Q. 2018. Soil aggregate size mediates the responses of microbial communities to crop rotation. European Journal of Soil Biology 88:48-56. https://doi.org/10.1016/j.ejsobi.2018.06.004

Liu J, Sui Y, Yu Z, Shi Y, Chu H, Jin J, Liu X, and Wang G. 2015. Soil carbon content drives the biogeographical distribution of fungal communities in the black soil zone of northeast China. Soil Biology and Biochemistry 83:29-39. https://doi.org/10.1016/j.soilbio.2015.01.009

Maarastawi SA, Frindte K, Linnartz M, and Knief C. 2018. Crop rotation and straw application impact microbial communities in italian and philippine soils and the rhizosphere of Zea mays. Frontiers in Microbiology. p 1295.

Meerupati T, Andersson K-M, Friman E, Kumar D, Tunlid A, and Ahrén D. 2013. Genomic mechanisms accounting for the adaptation to parasitism in nematode-trapping fungi. PLoS Genetics 9:1-20. 10.1371/journal.pgen.1003909

Mueller R, Belnap J, and Kuske C. 2015. Soil bacterial and fungal community responses to nitrogen addition across soil depth and microhabitat in an arid shrubland. Frontiers in Microbiology 6. 10.3389/fmicb.2015.00891

Ochoa-Hueso R, Collins SL, Delgado-Baquerizo M, Hamonts K, Pockman WT, Sinsabaugh RL, Smith MD, Knapp AK, and Power SA. 2018. Drought consistently alters the composition of soil fungal and bacterial communities in grasslands from two continents. Global Change Biology 
485

486

487

488

489

490

491

492

493

494

495

496

497

498

499

500

501

502

503

504

505

506

507

508

509

510

511

24:2818-2827. 10.1111/gcb.14113

Ohm RA, Feau N, Henrissat B, Schoch CL, Horwitz BA, Barry KW, Condon BJ, Copeland AC, Dhillon B, Glaser F, Hesse CN, Kosti I, LaButti K, Lindquist EA, Lucas S, Salamov AA, Bradshaw RE, Ciuffetti L, Hamelin RC, Kema GHJ, Lawrence C, Scott JA, Spatafora JW, Turgeon BG, de Wit PJGM, Zhong S, Goodwin SB, and Grigoriev IV. 2012. Diverse lifestyles and strategies of plant pathogenesis encoded in the genomes of eighteen Dothideomycetes fungi. PLoS pathogens 8:e1003037. 10.1371/journal.ppat.1003037

Schlatter DC, Schillinger WF, Bary AI, Sharratt B, and Paulitz TC. 2017. Biosolids and conservation tillage: Impacts on soil fungal communities in dryland wheat-fallow cropping systems. Soil Biology and Biochemistry 115:556-567.

https://doi.org/10.1016/j.soilbio.2017.09.021

Schoch CL, Crous PW, Groenewald JZ, Boehm EWA, Burgess TI, de Gruyter J, de Hoog GS, Dixon LJ, Grube M, Gueidan C, Harada Y, Hatakeyama S, Hirayama K, Hosoya T, Huhndorf SM, Hyde KD, Jones EBG, Kohlmeyer J, Kruys Å, Li YM, Lücking R, Lumbsch HT, Marvanová L, Mbatchou JS, McVay AH, Miller AN, Mugambi GK, Muggia L, Nelsen MP, Nelson P, Owensby CA, Phillips AJL, Phongpaichit S, Pointing SB, Pujade-Renaud V, Raja HA, Plata ER, Robbertse B, Ruibal C, Sakayaroj J, Sano T, Selbmann L, Shearer CA, Shirouzu T, Slippers B, Suetrong S, Tanaka K, Volkmann-Kohlmeyer B, Wingfield MJ, Wood AR, Woudenberg JHC, Yonezawa H, Zhang Y, and Spatafora JW. 2009. A class-wide phylogenetic assessment of Dothideomycetes. Studies in Mycology 64:1-15.

https://doi.org/10.3114/sim.2009.64.01

Seena S, Duarte S, Pascoal C, and Cássio F. 2012. Intraspecific variation of the aquatic fungus articulospora tetracladia: An ubiquitous perspective. Plos One 7:e35884.

10.1371/journal.pone.0035884

Six J, Bossuyt H, Degryze S, and Denef K. 2004. A history of research on the link between (micro)aggregates, soil biota, and soil organic matter dynamics. Soil and Tillage Research 79:731. https://doi.org/10.1016/j.still.2004.03.008 
512 Six J, Frey SD, Thiet RK, and Batten KM. 2006. Bacterial and fungal contributions to carbon 513 sequestration in agroecosystems. Soil Science Society of America Journal 70:555--569.

514 Tatagiba SD, DaMatta FM, and Rodrigues FA. 2016. Silicon partially preserves the 515 photosynthetic performance of rice plants infected by Monographella albescens. Annals of 516 Applied Biology 168:111-121. doi:10.1111/aab.12246

517 Wang D, Fonte SJ, Parikh SJ, Six J, and Scow KM. 2017a. Biochar additions can enhance soil 518 structure and the physical stabilization of C in aggregates. Geoderma 303:110-117.

519 https://doi.org/10.1016/j.geoderma.2017.05.027

520 Wang J, Song Y, Ma T, Raza W, Li J, Howland JG, Huang Q, and Shen Q. 2017b. Impacts of 521 inorganic and organic fertilization treatments on bacterial and fungal communities in a paddy

522 soil. Applied Soil Ecology 112:42-50. https://doi.org/10.1016/j.apsoil.2017.01.005

523 Wang X, Wang C, Sui J, Liu Z, Li Q, Ji C, Song X, Hu Y, Wang C, and Sa R. 2018. Isolation 524 and characterization of phosphofungi, and screening of their plant growth-promoting activities. 525 Amb Express 8:63.

526 Warnock DD, Mummey DL, McBride B, Major J, Lehmann J, and Rillig MC. 2010. Influences 527 of non-herbaceous biochar on arbuscular mycorrhizal fungal abundances in roots and soils:

528 Results from growth-chamber and field experiments. Applied Soil Ecology 46:450-456.

529 https://doi.org/10.1016/j.apsoil.2010.09.002

$530 \mathrm{Xu} \mathrm{N}$, Tan G, Wang H, and Gai X. 2016. Effect of biochar additions to soil on nitrogen leaching, 531 microbial biomass and bacterial community structure. European Journal of Soil Biology 74:1-8. 532 https://doi.org/10.1016/j.ejsobi.2016.02.004

533 Yan H-T, Yin Q-Y, Ding S-S, Ren T-B, Xu J-L, Zong H, Gao Q, and Liu G-S. 2018. Effect of 534 biochar amendment on physicochemical properties and fungal community structures of 535 cinnamon soil. Huan jing ke xue 39:2412-2419. 10.13227/j.hjkx.201711114 536 Yu Z, Li Y, Hu X, Jin J, Wang G, Tang C, Liu J, Liu X, Franks A, Egidi E, and Xie Z. 2018. 537 Elevated $\mathrm{CO}_{2}$ increases the abundance but simplifies networks of soybean rhizosphere fungal 538 community in Mollisol soils. Agriculture, Ecosystems \& Environment 264:94-98. 
539 https://doi.org/10.1016/j.agee.2018.05.006

540 Zhao H, Shar AG, Li S, Chen Y, Shi J, Zhang X, and Tian X. 2018. Effect of straw return mode

541 on soil aggregation and aggregate carbon content in an annual maize-wheat double cropping

542 system. Soil and Tillage Research 175:178-186. https://doi.org/10.1016/j.still.2017.09.012

543 Zheng J, Chen J, Pan G, Liu X, Zhang X, Li L, Bian R, Cheng K, and Jinwei Z. 2016. Biochar

544 decreased microbial metabolic quotient and shifted community composition four years after a

545 single incorporation in a slightly acid rice paddy from southwest China. Science of The Total

546 Environment 571:206-217. https://doi.org/10.1016/j.scitotenv.2016.07.135

547 Zhou J, Jiang X, Zhou B, Zhao B, Ma M, Guan D, Li J, Chen S, Cao F, Shen D, and Qin J. 2016.

548 Thirty four years of nitrogen fertilization decreases fungal diversity and alters fungal community

549 composition in black soil in northeast China. Soil Biology and Biochemistry 95:135-143.

550 https://doi.org/10.1016/j.soilbio.2015.12.012 


\section{Table $\mathbf{1}$ (on next page)}

Physicochemical characteristics of soil samples under different fertilization treatments and different depths.

Data (Average $\pm S E, n=3$ ) in the same column with different letters indicates significant differences according to LSD test $(p<0.05)$. The "a" and "a'" represent the ANOVA results for $0-20 \mathrm{~cm}$ and $20-40 \mathrm{~cm}$ soils, respectively. 


\begin{tabular}{|c|c|c|c|c|c|}
\hline $\begin{array}{l}\text { Depth } \\
(\mathrm{cm})\end{array}$ & Treatments & $\begin{array}{c}\mathrm{pH} \\
\left(\mathrm{H}_{2} \mathrm{O}\right)\end{array}$ & $\begin{array}{c}\mathrm{SOC} \\
\left(\mathrm{g} \mathrm{kg}^{-1}\right)\end{array}$ & $\begin{array}{c}\mathrm{TN} \\
\left(\mathrm{g} \mathrm{kg}^{-1}\right)\end{array}$ & $\begin{array}{c}\mathrm{EC} \\
\left(\mathrm{mS} \mathrm{cm}^{-1}\right)\end{array}$ \\
\hline \multirow{4}{*}{$0-20$} & $\mathrm{CK}$ & $8.90 \pm 0.16 \mathrm{a}$ & $7.98 \pm 1.51 \mathrm{~b}$ & $1.05 \pm 0.19$ & $0.05 \pm 0.01$ \\
\hline & $\mathrm{CF}$ & $8.21 \pm 0.55 \mathrm{ab}$ & $9.09 \pm 0.70 \mathrm{~b}$ & $0.91 \pm 0.08$ & $0.04 \pm 0.02$ \\
\hline & $\mathrm{CS}$ & $8.01 \pm 0.42 \mathrm{~b}$ & $9.61 \pm 3.27 \mathrm{ab}$ & $0.94 \pm 0.07$ & $0.05 \pm 0.01$ \\
\hline & $\mathrm{CB}$ & $8.60 \pm 0.24 \mathrm{ab}$ & $13.08 \pm 0.58 \mathrm{a}$ & $0.97 \pm 0.14$ & $0.04 \pm 0.00$ \\
\hline \multirow{4}{*}{$20-40$} & $\mathrm{CK}$ & $8.81 \pm 0.27$ & $3.31 \pm 0.91 b^{\prime}$ & $0.86 \pm 0.10 \mathrm{~b}$ & $0.04 \pm 0.01 \mathrm{ab}$ \\
\hline & $\mathrm{CF}$ & $8.44 \pm 0.53$ & $3.10 \pm 0.69 \mathrm{~b}$ & $0.85 \pm 0.02 \mathrm{~b}$ & $0.05 \pm 0.02 \mathrm{ab}$ \\
\hline & $\mathrm{CS}$ & $8.48 \pm 0.25$ & $5.01 \pm 0.30 \mathrm{a}^{\prime}$ & $1.13 \pm 0.11 \mathrm{a}^{\prime}$ & $0.03 \pm 0.01 \mathrm{~b}$ \\
\hline & $\mathrm{CB}$ & $8.73 \pm 0.04$ & $5.54 \pm 1.17 \mathrm{a}^{\prime}$ & $1.00 \pm 0.06 \mathrm{a}^{\prime}$ & $0.05 \pm 0.01 \mathrm{a}^{\prime}$ \\
\hline
\end{tabular}




\section{Table 2 (on next page)}

Effects of different treatments on the stability indices of soil aggregates.

Data in the table are Mean $\pm S E, n=3$. Different lowercase letters in the same column refer to significant difference according to LSD test $(p<0.05)$. The "a" and "a'" represent the ANOVA results for $0-20$ and $20-40 \mathrm{~cm}$ soils, respectively. 


\begin{tabular}{|c|c|c|c|c|}
\hline $\begin{array}{l}\text { Soil depth } \\
\text { (cm) }\end{array}$ & Treatments & MWD (mm) & GMD (mm) & $\mathrm{D}$ \\
\hline \multirow{4}{*}{$0-20$} & $\mathrm{CK}$ & $0.61 \pm 0.03 \mathrm{c}$ & $0.33 \pm 0.01 \mathrm{c}$ & $2.971 \pm 0.054 \mathrm{a}$ \\
\hline & $\mathrm{CF}$ & $0.65 \pm 0.03 \mathrm{c}$ & $0.34 \pm 0.02 \mathrm{c}$ & $2.961 \pm 0.072 \mathrm{a}$ \\
\hline & $\mathrm{CS}$ & $0.76 \pm 0.04 \mathrm{~b}$ & $0.44 \pm 0.03 \mathrm{~b}$ & $2.925 \pm 0.036 b$ \\
\hline & $\mathrm{CB}$ & $0.84 \pm 0.04 \mathrm{a}$ & $0.50 \pm 0.03 \mathrm{a}$ & $2.917 \pm 0.074 \mathrm{~b}$ \\
\hline \multirow{4}{*}{$20-40$} & $\mathrm{CK}$ & $0.38 \pm 0.02 \mathrm{c}$ & $0.19 \pm 0.01 \mathrm{c}^{\prime}$ & $2.987 \pm 0.032 \mathrm{a}$ \\
\hline & $\mathrm{CF}$ & $0.46 \pm 0.03 \mathrm{~b}$ & $0.23 \pm 0.01 \mathrm{~b}$ & $2.982 \pm 0.048 \mathrm{a}$ \\
\hline & $\mathrm{CS}$ & $0.57 \pm 0.02 \mathrm{a}^{\prime}$ & $0.32 \pm 0.02 \mathrm{a}^{\prime}$ & $2.969 \pm 0.059 \mathrm{~b}$ \\
\hline & $\mathrm{CB}$ & $0.60 \pm 0.02 \mathrm{a}^{\prime}$ & $0.33 \pm 0.01 \mathrm{a}^{\prime}$ & $2.964 \pm 0.035 \mathrm{~b}$ \\
\hline
\end{tabular}

1 


\section{Table 3(on next page)}

The summarized statistically relevant abundance differences of the dominant fungal genera in the surface soil $(0-20 \mathrm{~cm})$.

Different lowercase letters at each aggregate distribution and each fungal genus indicate significant differences at $p<0.05$ according to LSD test. 


\begin{tabular}{|c|c|c|c|c|c|c|c|c|c|c|c|c|}
\hline \multirow{2}{*}{ Items } & \multicolumn{4}{|c|}{ Macroaggrergates } & \multicolumn{4}{|c|}{ Microaggregates } & \multicolumn{4}{|c|}{ Silt clay } \\
\hline & $\mathrm{CK}$ & $\mathrm{CF}$ & $\mathrm{CS}$ & $\mathrm{CB}$ & $\mathrm{CK}$ & $\mathrm{CF}$ & $\mathrm{CS}$ & $\mathrm{CB}$ & $\mathrm{CK}$ & $\mathrm{CF}$ & $\mathrm{CS}$ & $\mathrm{CB}$ \\
\hline Pyrenochaetopsis & $\mathrm{a}$ & $\mathrm{ab}$ & $\mathrm{ab}$ & $\mathrm{b}$ & $a b$ & $\mathrm{a}$ & $\mathrm{bc}$ & $\mathrm{c}$ & $\mathrm{ab}$ & $\mathrm{a}$ & $\mathrm{b}$ & $\mathrm{b}$ \\
\hline unclassified_c__Dothideomycetes & & & & & & & & & a & $\mathrm{b}$ & $\mathrm{b}$ & $\mathrm{b}$ \\
\hline unclassified_k__Fungi & & & & & $\mathrm{b}$ & $\mathrm{a}$ & $a b$ & $\mathrm{a}$ & & & & \\
\hline unclassified_o_Pleosporales & & & & & & & & & $\mathrm{b}$ & a & $\mathrm{bc}$ & $\mathrm{c}$ \\
\hline Gibberella & & & & & $\mathrm{ab}$ & $\mathrm{a}$ & $\mathrm{b}$ & $\mathrm{b}$ & & & & \\
\hline unclassified_o__Coniochaetales & $\mathrm{ab}$ & $\mathrm{ab}$ & $\mathrm{a}$ & $\mathrm{b}$ & bc & $\mathrm{a}$ & $a b$ & $\mathrm{c}$ & $\mathrm{b}$ & $\mathrm{a}$ & $a b$ & $\mathrm{~b}$ \\
\hline Monographella & $\mathrm{a}$ & $\mathrm{a}$ & $\mathrm{ab}$ & $\mathrm{b}$ & & & & & & & & \\
\hline Articulospora & $\mathrm{ab}$ & $\mathrm{b}$ & $\mathrm{b}$ & a & & & & & & & & \\
\hline Westerdykella & $a b$ & $\mathrm{ab}$ & $\mathrm{a}$ & $\mathrm{b}$ & & & & & & & & \\
\hline
\end{tabular}




\section{Table 4 (on next page)}

The summarized statistically relevant abundance differences of the dominant fungal genera in the deep soil $(20-40 \mathrm{~cm})$.

Different lowercase letters at each aggregate distribution and each fungal genus indicate significant differences at $p<0.05$ according to LSD test. 


\begin{tabular}{|c|c|c|c|c|c|c|c|c|c|c|c|c|}
\hline & \multicolumn{4}{|c|}{ Macroaggrergates } & \multicolumn{4}{|c|}{ Microaggregates } & \multicolumn{4}{|c|}{ Silt clay } \\
\hline & CK & $\mathrm{CF}$ & $\mathrm{CS}$ & $\mathrm{CB}$ & CK & $\mathrm{CF}$ & $\mathrm{CS}$ & $\mathrm{CB}$ & $\mathrm{CK}$ & $\mathrm{CF}$ & $\mathrm{CS}$ & $\mathrm{CB}$ \\
\hline unclassified_k_Fungi & & & & & $\mathrm{a}$ & $\mathrm{ab}$ & $\mathrm{b}$ & $\mathrm{a}$ & & & & \\
\hline Neurospora & $b$ & $b$ & $\mathrm{~b}$ & $\mathrm{a}$ & & & & & & & & \\
\hline Pyrenochaetopsis & & & & & $\mathrm{ab}$ & $\mathrm{a}$ & b & b & $\mathrm{ab}$ & $\mathrm{a}$ & $a b$ & $\mathrm{~b}$ \\
\hline Neosetophoma & & & & & & & & & $\mathrm{a}$ & $b$ & $\mathrm{a}$ & $\mathrm{b}$ \\
\hline
\end{tabular}

1 


\section{Figure 1}

Effects of different treatments on the distribution of soil water-stable aggregates.

Data here are Mean $\pm S E, n=3$. Different lowercase letters in specific aggregate class refer to significant difference according to LSD test $(p<0.05)$. The "a" and "a'" represent the ANOVA results for $0-20$ and $20-40 \mathrm{~cm}$ soils, respectively.

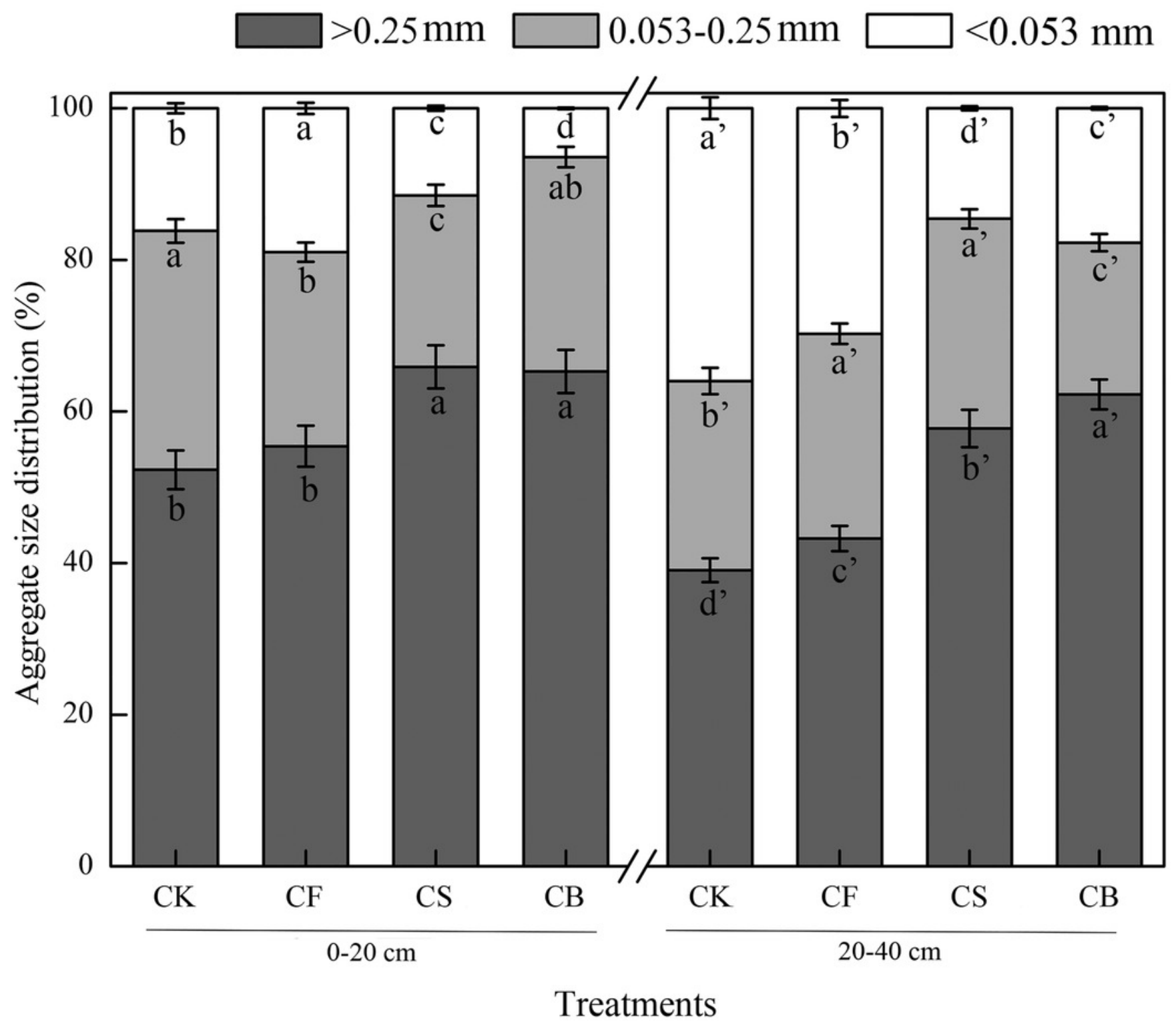


Figure 2

Alpha diversity analysis between the four treatments (CK, CF, CS, CB) in 0-20 (UP) and 20-40 (DW) cm soils, respectively.

The " $A$ " and " $B$ " in Group name refer to macroaggregate and microaggregate, respectively.

Figure 3

Principal co-ordinates analysis (PCOA) of soil fungal community in four different fertilization treatments $(\mathrm{CK}, \mathrm{CF}, \mathrm{CS}$, and $\mathrm{CB})$.

"UP" and "DW" referred to the soil depths of 0-20 and 20-40 cm, respectively. "A", "B", and " $\mathrm{C}$ " meant macroaggregate, microaggregate, and silt clay, respectively.

A

PCoA on OTU level

CSUPA $\triangle$ CSUPB

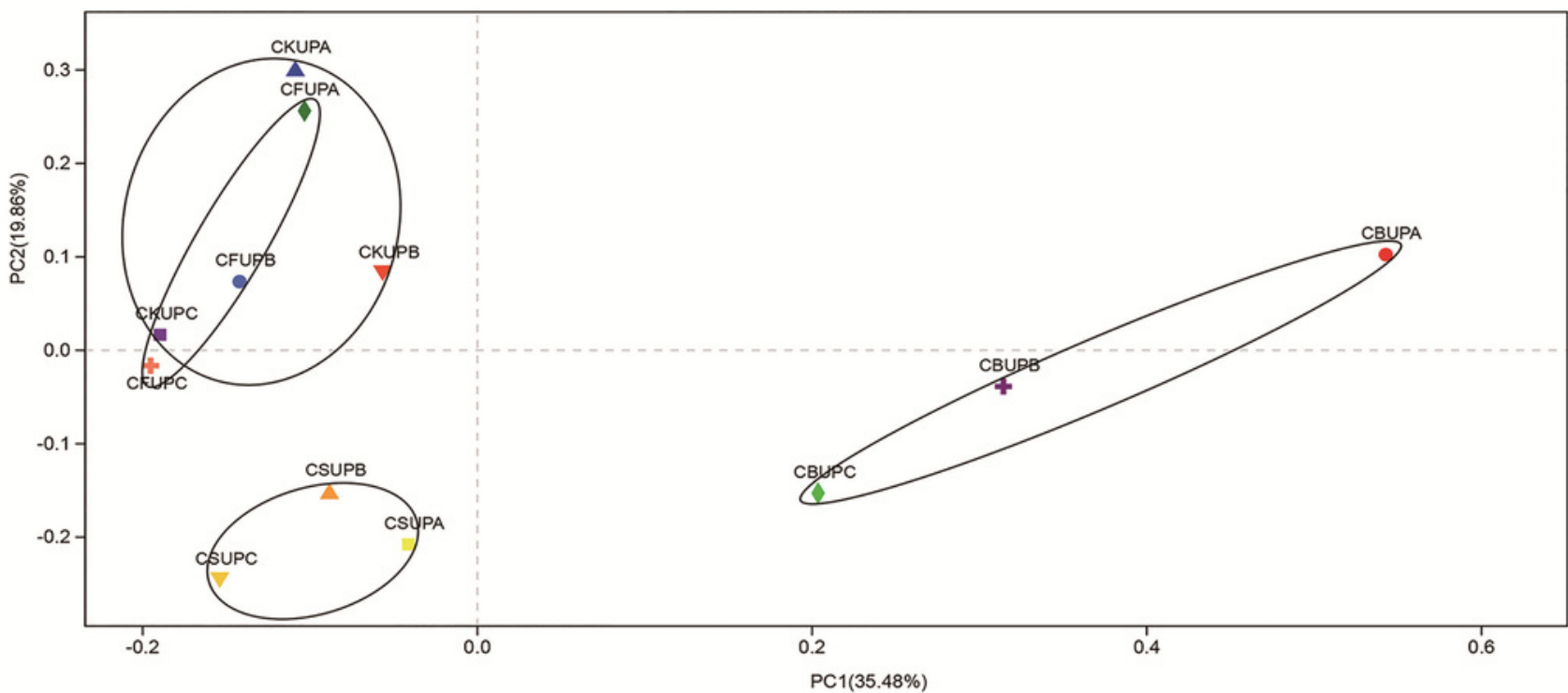

$\triangle$ CKUPA

$\nabla$ CKUPB

a CKUPC

- CBUPA

\# CBUPB

$\triangle$ CBUPC

$\checkmark$ CFUPA

- CFUPB

\# CFUPC

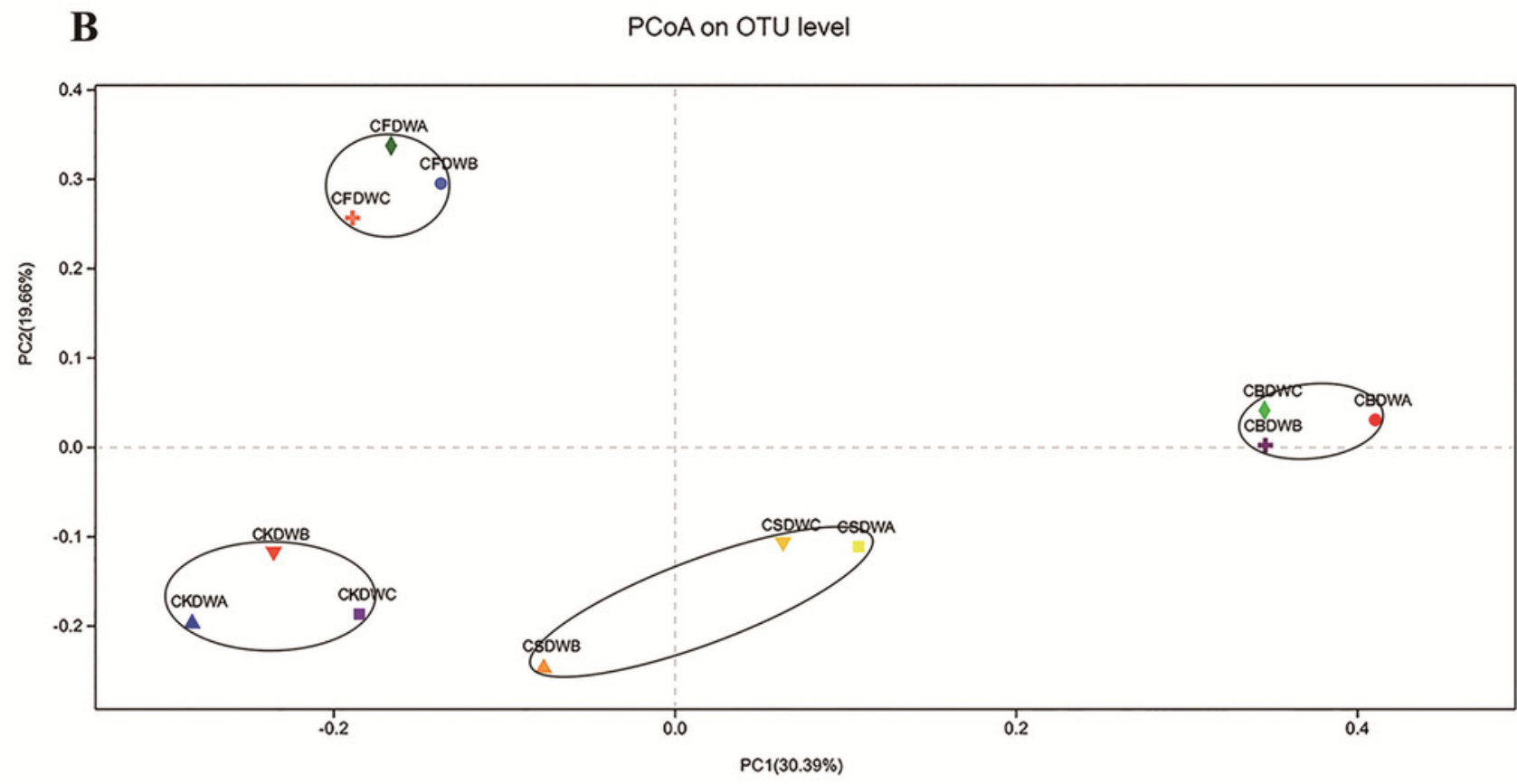

CSOWA 


\section{Figure 4}

Relative abundances of the dominant fungal classes for all the soil subsamples.

Relative abundances are based on the proportional frequencies of the DNA sequences that could be classified.




Figure 5

Summarized statistically differences of the dominant classes in the soil aggregates in 020 (A-E) and 20-40 cm (F-J) soil.

Different lowercase letters at each aggregate distribution and each class indicate significant differences at $p<0.05$ according to LSD test.
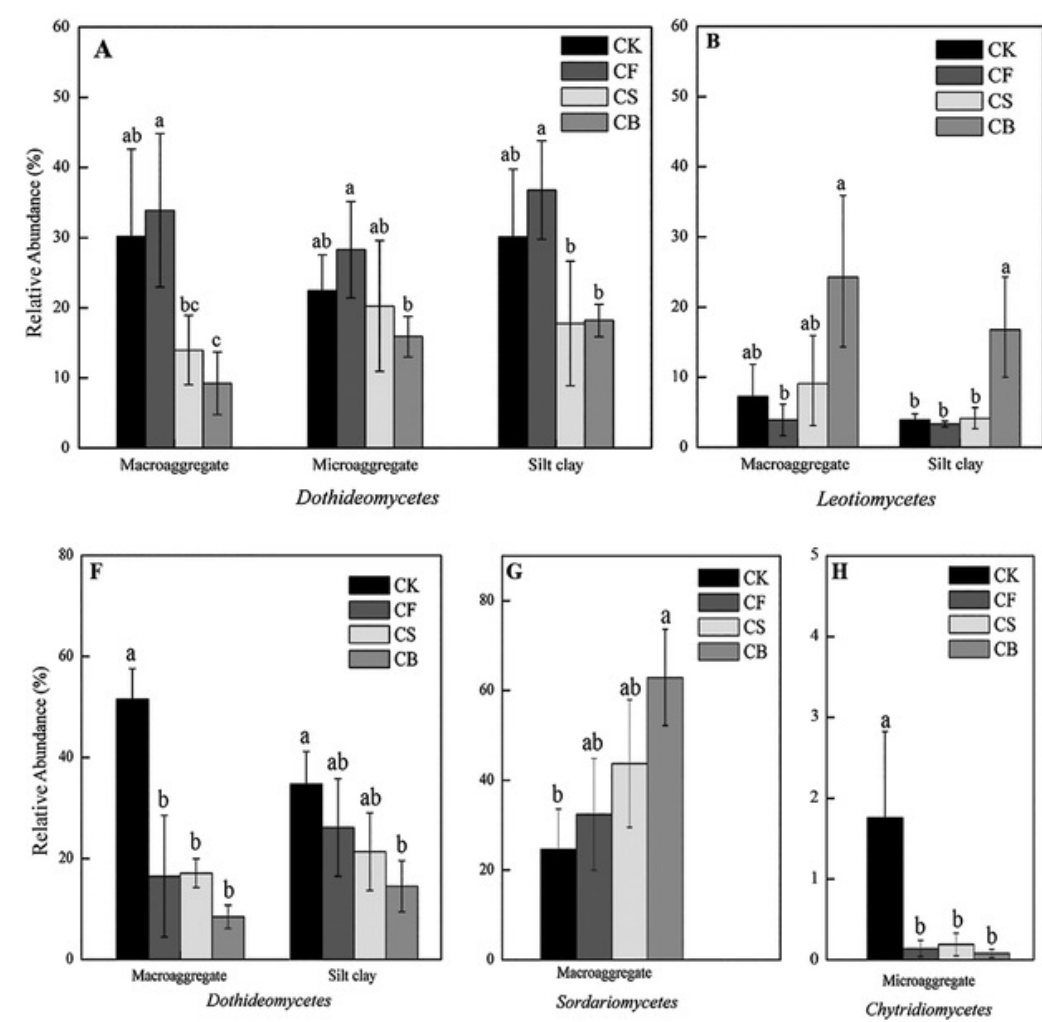
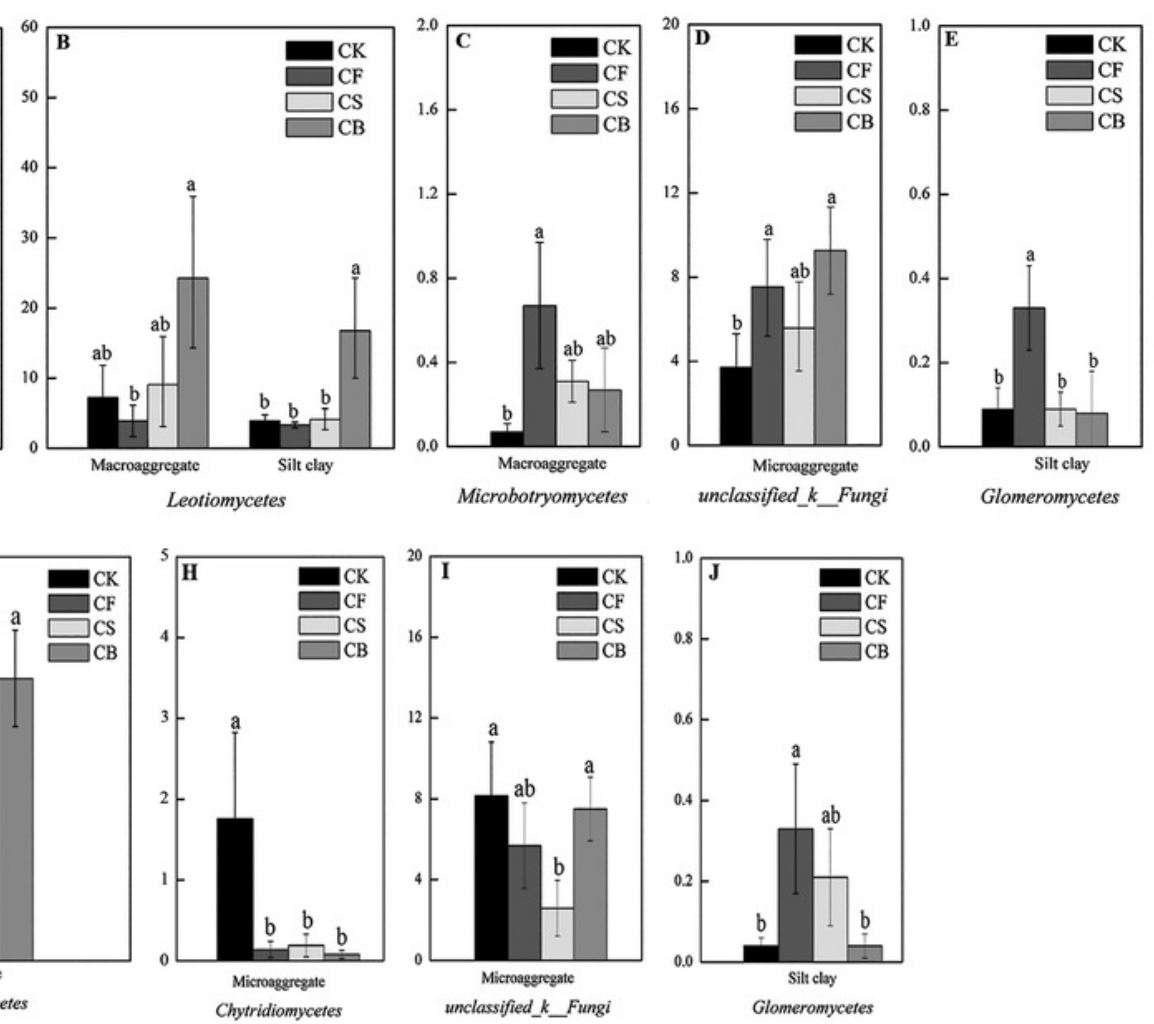